Article

\title{
Application of the Stripping Voltammetry Method for the Determination of Copper and Lead Hyperaccumulation Potential in Lunaria annua L.
}

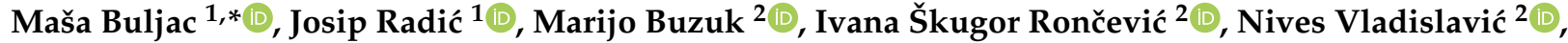 \\ Denis Krivić $^{3}$ and Ana Marijanović ${ }^{4}$
}

check for

updates

Citation: Buljac, M.; Radić, J.; Buzuk, M.; Škugor Rončević, I.; Vladislavić, N.; Krivić, D.; Marijanović, A. Application of the Stripping Voltammetry Method for the Determination of Copper and Lead Hyperaccumulation Potential in Lunaria annua L. Chemosensors 2022 10, 52. https://doi.org/10.3390/ chemosensors 10020052

Academic Editor: Constantin Apetrei

Received: 27 December 2021

Accepted: 27 January 2022

Published: 29 January 2022

Publisher's Note: MDPI stays neutral with regard to jurisdictional claims in published maps and institutional affiliations.

Copyright: (C) 2022 by the authors. Licensee MDPI, Basel, Switzerland. This article is an open access article distributed under the terms and conditions of the Creative Commons Attribution (CC BY) license (https:// creativecommons.org/licenses/by/ $4.0 /)$.
1 Department of Environmental Chemistry, Faculty of Chemistry and Technology, University of Split, 21000 Split, Croatia; jradic@ktf-split.hr

2 Department of General and Inorganic Chemistry, Faculty of Chemistry and Technology, University of Split, 21000 Split, Croatia; buzuk@ktf-split.hr (M.B.); skugor@ktf-split.hr (I.Š.R.); nives@ktf-split.hr (N.V.)

3 Division of Biophysics, Gottfried Schatz Research Center, Medical University of Graz, 8010 Graz, Austria; denis.krivic@medunigraz.at

4 Faculty of Chemistry and Technology, University of Split, 21000 Split, Croatia; anamarijanovic@ymail.com

* Correspondence: masa@ktf-split.hr; Tel.: +385-21-329-479

\begin{abstract}
Various species of the Brassicaceae family are known to hyperaccumulate metals. Lunaria annua L., a plant from the Brassicaceae family, is an oilseed crop known for its pharmaceutical and nutraceutical applications. In this work, Lunaria annua L. was investigated for its accumulation potential in copper and lead-contaminated soil. Concentrations of copper and lead were measured before planting (in seeds and soils) and after the plant was harvested (in soils and plant). Two types of soils were used: a soil sample collected from the Botanical Garden of the Faculty of Science, University of Split (soil 1, S1) and a commercially available organic mineral substrate (soil 2, S2). Measured pH values showed that the $\mathrm{S} 1$ ( $\mathrm{pH}=8.58)$ was moderately alkaline soil. On the other hand, the purchased organic soil, $\mathrm{S} 2(\mathrm{pH}=6.35)$, was poorly acidic to neutral. For the determination of copper $(\mathrm{Cu})$ and lead $(\mathrm{Pb})$, square wave anodic stripping voltammetry (SWASV), using a glassy carbon electrode modified with mercury film, was applied. The concentrations of $\mathrm{Pb}$ and $\mathrm{Cu}$ were determined and calculated in the sample using the standard addition method. Obtained results have shown that Lunaria annua L. is a lead hyperaccumulator (4116.2 $\mathrm{mg} / \mathrm{kg}$ in S1 and $3314.7 \mathrm{mg} / \mathrm{kg}$ in S2) and a potential copper accumulator $(624.2 \mathrm{mg} / \mathrm{kg}$ in S1 and $498.9 \mathrm{mg} / \mathrm{kg}$ in S2). Likewise, the results have shown that the higher the $\mathrm{pH}$ is, the lower the possibility that metal accumulation exists.
\end{abstract}

Keywords: Lunaria annua L.; accumulation; lead; copper; square wave anodic stripping voltammetry; standard addition method

\section{Introduction}

Heavy metals are pollutants that significantly affect the environment and their toxicity has been a problem of increasing significance for ecological, evolutionary, nutritional and environmental reasons [1]. Due to human activity and consequent environmental pollution, heavy metals enter the biosphere, where, due to their toxicity, they lead to certain changes in specific metabolic pathways in living organisms. In addition to the organisms, heavy metals reach the soil. Technological operations that are a part of everyday industrial workflows are the main cause of soil contamination by deposition of harmful substances. Further, agricultural processes and waste disposal sites, as well as air pollution and pollutant deposition by wastewater treatment, account for a large portion of soil contamination causative factors [2]. Interestingly, growing plants on soils that contained increased levels of heavy metals led to the discovery of the metal-accumulating properties of many species known today. However, not all heavy metals have a toxic effect on plants. In other words, normal plant growth requires the presence of heavy metals, which is why it up to the type 
of metal, its chemical form, $\mathrm{pH}$, the composition of soil or sole plant species whether a metal will have deleterious effects on a particular plant or not [1].

The majority of metals cannot be eliminated from the environment by chemical or biological transformation. They cause a state of oxidative stress in the plant and it is necessary to better understand the mechanisms of their harmful effects, as well as the tolerance of certain species and the specific reaction of their varieties to the increased availability of heavy metals in the environment.

Lead, as a non-essential trace metal, is a strong environmental pollutant that is toxic in very low concentrations and accumulates in various parts of the plant. Copper is a micronutrient highly important for plants because of its ability to maintain vital plant activity. Any deficiency of a nutrient affects plant growth and decreases crop yields [3]. There are different sources of lead and copper in the environment, such as natural sources (geologic parent material or sedimentary rock, volcanoes, marine sources) and industrial sources (energy supplying power stations, metallurgy and electroplating, chemical industry, pharmaceuticals). Other sources of heavy metals include waste incineration, landfills and transportation (cars, diesel-powered vehicles and aircraft) [1]. For copper to be biologically available, the $\mathrm{pH}$ should optimally be between 4.5 and 6, while the mobility of lead does not depend on the $\mathrm{pH}$ value of the soil and is quite small due to its tendency to bind to the organic matter [4].

Crop plants have been used to extract heavy metals from soil and sediments, followed by translocation of contaminants to the harvestable stalks and leaves of the plants [2] As many metals that are being stockpiled by plants are essential nutrients, there is great potential for their use in food fortification and phytoremediation. Thus, analysis of metal accumulation capacity represents a promising aspect of plant use [5]. Over 700 metalhyperaccumulating and tolerant plant species are known, particularly in the context of affinity towards Nickel (over 500) [6]. Species associated with storing cobalt, copper or zinc in higher amounts are second in rank, although much smaller in number, with those hyperaccumulating arsenic, cadmium, gold, lead, manganese and thallium being in the third place [7].

According to Baker and Brooks [8], the largest numbers of hyperaccumulating species belong to the Brassicaceae family. Likewise, Sarma emphasizes in his paper [9] that metal hyperaccumulation is a property widespread among the representatives of the Brassicaceae family. $\mathrm{Ni}$ and $\mathrm{Zn}$ hyperaccumulation, the former being first discovered in 1948 in Alyssum bertolonii/Brassicaceae, and later in 1865 in Noccaea caerulescens (formerly, Thlaspi caerulescens)/Brassicaceae, began to attract increasing attention in the early 1990s as incidences of the alternative metal accumulating strategies [10].

A hyperaccumulator has been defined as a plant that can accumulate cadmium $(>100 \mathrm{mg} / \mathrm{kg})$, copper and lead $(>1000 \mathrm{mg} / \mathrm{kg})$, zinc $(>10.000 \mathrm{mg} / \mathrm{kg})$ in its shoot dry matter. Further, in these plants, metal concentrations in shoots are greater than in roots, showing a peculiar ability of a plant to absorb and transport metals, and store them in their above-ground parts [8]. A plethora of factors affect hyperaccumulation, and some of them are described in the work of Peng et al. [6].

Brassicaceae plants often feature regularly in diets as raw or preserved vegetables and vegetable oil [11].

Lunaria annua $\mathrm{L}$. is a biennial cruciferous oilseed crop. The biennial character of Lunaria is the main constraint for economically feasible cultivation. The seeds contain $30-35 \%$ oil, which contains $67 \%$ of long-chain fatty acids (44\% erucic acid, C22:1, and $23 \%$ nervonic acid, C24:1). The oil is suitable as a lubricant [12,13]. In representatives of the genus, the boiled root of a plant is edible, while unripe fruits can be chopped and used as a spice.

Determinations of heavy metals in environmental samples, whether qualitative or quantitative, can be performed using different spectroscopic and electroanalytical methods. These include atomic absorption spectrometry (AAS), inductively coupled plasma atomic emission spectroscopy (ICP-AES) [14], microwave-induced plasma optical emission spectroscopy (MIP-OES), inductively coupled plasma optical emission (ICP-OES) and 
stripping voltammetry [15]. The latter is a widely used electrochemical technique for the detection of heavy metals in soil and water samples due to its ability to measure metal ions at trace concentrations. Stripping analysis consisted of two steps, a preconcentration and a stripping one. During the former one, the metal ions were reduced to a metal of interest and accumulated on the surface of a working electrode; during the latter, by applying a positive (anodic) or negative (cathodic) potential scan to the electrode, a metal of interest was oxidized back to its ion form and stripped out into the solution. In the meantime, the amount of the element was determined by measuring the generated current [3].

In this work, we investigated the accumulation properties of Lunaria annua L. in the context of copper and lead-abundant soil. Metal concentrations of copper and lead were measured before planting and after the plants were harvested in soils, seeds and plants depending on the stage of growth. COMPO SANA, a commercially available organic mineral substrate and a soil sample collected from the Botanical Garden of the Faculty of Science, University of Split (30 cm-deep soil surface), were used in these experiments.

For the determination of $\mathrm{Cu}$ and $\mathrm{Pb}$, square wave anodic stripping voltammetry (SWASV), using a glassy carbon electrode modified with mercury film, was applied. The standard addition method was used to determine and calculate the concentrations of copper and lead.

\section{Materials and Methods}

\subsection{Chemicals and Materials}

All chemicals and reagents were at least of analytical grade, and Milli-Q water was used throughout the experiment. Lead(II) nitrate, potassium nitrate and phosphoric acid were purchased from T.T.T. (Zagreb, Croatia); copper(II) nitrate, mercury(II) nitrate monohydrate and sulfuric acid were purchased from Kemika (Zagreb, Croatia). Nitric acid was purchased from Merck (Darmstadt, Germany). Hydrochloric acid was purchased from VWR Chemicals (Radnor, Pennsylvania, SAD). Ethanol was purchased from Gram-mol (Zagreb, Croatia). Standard solutions $\left(1 \times 10^{-5} \mathrm{M}\right)$ of each metal were prepared by dissolving exact salt weight $\left.\left(\mathrm{Pb}\left(\mathrm{NO}_{3}\right)_{2}\right), \mathrm{Cu}\left(\mathrm{NO}_{3}\right)_{2} \times 3 \mathrm{H}_{2} \mathrm{O}\right)$ in $100 \mathrm{~mL}$ deionized water.

All experiments were carried out in a conventional three-electrode electrochemical cell at $25^{\circ} \mathrm{C}$. The glassy carbon $(\phi=3 \mathrm{~mm})$ served as a working electrode, $\mathrm{Ag} / \mathrm{AgCl} / 3$ $\mathrm{M} \mathrm{KCl}$ as a reference electrode and platinum as an auxiliary electrode. Electrochemical measurements were carried out using a potentiostat (Autolab PGSTAT 302N), connected to a PC and driven by the GPES4.9 software (Eco Chemie).

The supporting electrolyte required for the determination of $\mathrm{Pb}$ (II) and $\mathrm{Cu}(\mathrm{II})$ was a mixture of $0.01 \mathrm{M} \mathrm{H}_{3} \mathrm{PO}_{4}$ and $0.01 \mathrm{M} \mathrm{HNO}_{3}$ acids. To eliminate the influence of matrix in soil samples, measurements were performed with the addition of $100 \mu \mathrm{L}$ aqua regia $(2 \mathrm{~mL}$ of concentrated $\mathrm{HNO}_{3}$ and $6 \mathrm{~mL}$ of concentrated $\mathrm{HCl}$ into a $50 \mathrm{~mL}$ volumetric flask and filled with deionized water up to the volume). All experiments were carried out at room temperature (approximately $25^{\circ} \mathrm{C}$ ) without removing the dissolved gases.

\subsection{Sample Preparation}

\subsubsection{Preparation of Soil Samples}

The soil sample collected from the Botanical Garden (hereinafter S1) and a commercially available organic mineral substrate (COMPO SANA) (hereinafter S2) were air-dried for three weeks, mixed into a homogenous mixture and then sieved through a $2.5 \mathrm{~mm}$, $1.0 \mathrm{~mm}, 0.5 \mathrm{~mm}$ and $0.25 \mathrm{~mm}$ mesh.

In total, $1.0 \mathrm{~g}$ of each soil sample was put on porcelain crucibles, placed in a cool muffle furnace and ashed at $550{ }^{\circ} \mathrm{C}$ for $3 \mathrm{~h}$. Afterwards, the ashes were cooled and dissolved in $8 \mathrm{~mL}$ of aqua regia. The solution was filtered, the ashes were washed with diluted aqua regia and the filtrate was transferred into a $50 \mathrm{~mL}$ volumetric flask and diluted to the mark with deionized water.

For soil $\mathrm{pH}$ determination, two replicates of a $10.00 \mathrm{~g}$ portion of each soil sample were individually transferred to $50 \mathrm{~mL}$ glass beakers, and $25 \mathrm{~mL}$ of Milli-Q water $(\Omega=18.2 \mathrm{M} \Omega / \mathrm{cm})$ 
was added. A premium hotplate stirrer model MSH-20A (Witeg Labortechnik, GmbH, Wertheim, Germany) was used for stirring the solutions. The $\mathrm{pH}$ of the samples was measured using a $\mathrm{pH} /$ conductivity combimeter (Orion Star Series Meter Thermo Fischer Scientifc Inc., Beverly, MA, USA).

\subsubsection{Preparation of Seeds Samples}

In total, $1.0 \mathrm{~g}$ of the plant was put on porcelain crucibles, placed in a cool muffle furnace and ashed at $550{ }^{\circ} \mathrm{C}$ for $3 \mathrm{~h}$. Afterwards, the ashes were cooled and dissolved in $8 \mathrm{~mL}$ of aqua regia. The solution was filtered, the ashes were washed with diluted aqua regia and the filtrate was transferred into a $50 \mathrm{~mL}$ volumetric flask and diluted to the mark with deionized water.

\subsubsection{Preparation of Plant Samples}

Four flowerpots were prepared for each plant species; two of them were filled with S1, and two of them with S2. The seeds of Lunaria annua L. were planted in the flowerpots with the prepared soils. Two flower pots were watered with $15 \mathrm{~mL}$ of tap water of pH 7 (samples $\mathrm{S} 1+\mathrm{H}_{2} \mathrm{O}$ and $\mathrm{S} 2+\mathrm{H}_{2} \mathrm{O}$ ) and the other two with $15 \mathrm{~mL}$ of a prepared solution which contained $8 \mathrm{mM}$ of $\mathrm{Pb}\left(\mathrm{NO}_{3}\right)_{2}$ and $8 \mathrm{mM} \mathrm{Cu}\left(\mathrm{NO}_{3}\right)_{2} \times 3 \mathrm{H}_{2} \mathrm{O}$ (samples $\mathrm{S} 1+\mathrm{Pb} / \mathrm{Cu}$ and $\mathrm{S} 2+\mathrm{Pb} / \mathrm{Cu}$ ), for thirty days. Unseeded and untreated soils were used as controls.

After thirty days of cultivation, when plants had flowered, a plant from each flowerpot was harvested and left to dry at room temperature (ca. $25^{\circ} \mathrm{C}$ ) over a period of two days, and afterwards, in a laboratory drying oven at $75^{\circ} \mathrm{C}$ to a constant mass, in order to obtain dry mass. Plant samples were cut to pieces and milled into a homogenous powder. In total, $1.0 \mathrm{~g}$ of a plant was put in a porcelain crucible, placed in a cool muffle furnace and ashed at $550{ }^{\circ} \mathrm{C}$ for $3 \mathrm{~h}$. Afterwards, the ashes were cooled and dissolved in $8 \mathrm{~mL}$ of aqua regia. The solution was filtered, the ashes were washed with diluted aqua regia and the filtrate was transferred into a $50 \mathrm{~mL}$ volumetric flask and diluted to the mark with deionized water.

\subsection{Electrode Preparation}

A working electrode was polished with alumina powder to obtain a mirror-like surface, washed with deionized water, sonicated in ethanol solution for 2 min, washed with deionized water and dried. After, the electrode was electrochemically cleaned in $0.5 \mathrm{M}$ sulfuric acid in the potential area of $-1 \mathrm{~V}$ to $1 \mathrm{~V}$, and the scan rate of $0.2 \mathrm{Vs}^{-1}$.

Plating was carried out by immersion in a solution of $0.1 \mathrm{M} \mathrm{KNO}_{3}, 0.01 \mathrm{M} \mathrm{HNO}_{3}$ and $2 \times 10^{-4} \mathrm{M} \mathrm{Hg}\left(\mathrm{NO}_{3}\right)_{2} \times \mathrm{H}_{2} \mathrm{O}$, while the electrode potential was held at $-1.0 \mathrm{~V}$ for $2 \mathrm{~min}$. After each experiment, the electrode was electrochemically re-prepared, and the mercury film was cleaned by wiping the electrode with a wet tissue, followed by plating a new mercury film for performing a new experiment.

\subsection{Voltammetric Measurements}

The concentrations of lead and copper were determined using the square wave anodic stripping voltammetry (SWASV) under optimized parameters, i.e., electrodeposition potential and final potential of -1.5 and $+0.25 \mathrm{~V}$, respectively; electrodeposition time of $60 \mathrm{~s}$; step potential $=2 \mathrm{mV}$, step amplitude $=25 \mathrm{mV}$, and frequency $=10 \mathrm{~Hz}$.

Before the measurements, to avoid any contamination, the electrochemical cell was rinsed with concentrated $\mathrm{HNO}_{3}$ and Milli-Q water.

\subsection{Analysis of Samples}

In total, $50 \mathrm{~mL}$ of supporting electrolyte was transferred into an electrochemical cell, $100 \mu \mathrm{L}$ of each digested soil or plant sample and $100 \mu \mathrm{L}$ of aqua regia was added. The solution was stirred thoroughly and the potential was scanned. The obtained values of the peak current are given in the results chapter and were used to determine the concentrations of $\mathrm{Pb}$ and $\mathrm{Cu}$ in samples, respectively. 


\subsection{Standard Addition Method}

The standard addition method was used to determine the concentrations of metals in samples and to eliminate the matrix effects. In total, $100 \mu \mathrm{L}$ of a prepared sample and a particular volume of standard solutions $\left(1 \times 10^{-5} \mathrm{M}\right)$ of each metal were transferred into a $50 \mathrm{~mL}$ volumetric flask. The peak current value, relevant to each addition, was plotted on the $y$-axis, while the $x$-axis was graduated in terms of the concentration of a standard in the cell. The regression line was calculated and extrapolated back to the point on the $x$-axis at which $y=0$. The content of the determined element in the sample $(\mathrm{w})$ was calculated according to the following equation:

$$
\mathrm{w}\left(\mathrm{mg} \mathrm{kg}^{-1}\right)=-c_{x}\left(\mathrm{~mol} \mathrm{~L}^{-1}\right) \times \mathrm{M}\left(\mathrm{metal} / \mathrm{gmol}^{-1}\right) \times 2.5 \times 10^{7}
$$

where $2.5 \times 10^{7}$ represents the correlation factor.

\section{Results}

\subsection{Simultaneous Determination of $\mathrm{Cu}(\mathrm{II})$ and $\mathrm{Pb}(\mathrm{II})$}

Since certain concentrations of lead and copper can be found in real samples at the same time, combinations were developed with constant $\mathrm{Pb}^{2+}\left(1 \times 10^{-7} \mathrm{M}\right)$ with different additions of $\mathrm{Cu}^{2+}\left(1 \times 10^{-6} ; 1 \times 10^{-7} ; 1 \times 10^{-8} \mathrm{M}\right)$ and constant $\mathrm{Cu}^{2+}\left(1 \times 10^{-5} \mathrm{M}\right)$ with different additions of $\mathrm{Pb}^{2+}\left(1 \times 10^{-7} ; 1 \times 10^{-8} ; 1 \times 10^{-9} \mathrm{M}\right)$.

The reductive peak currents for the $\mathrm{Cu}$ and $\mathrm{Pb}$ ions increased linearly with an increase in their respective concentrations without affecting the other peak currents (Figure 1). It is obvious that copper and lead do not interfere with each other. The reduction peak potentials of the $\mathrm{Cu}$ and $\mathrm{Pb}$ ions on the modified electrode were separated completely into two well-defined peaks at $0.00 \mathrm{~V}$ and $-0.44 \mathrm{~V}$ vs. $\mathrm{Ag} / \mathrm{AgCl}$, respectively.

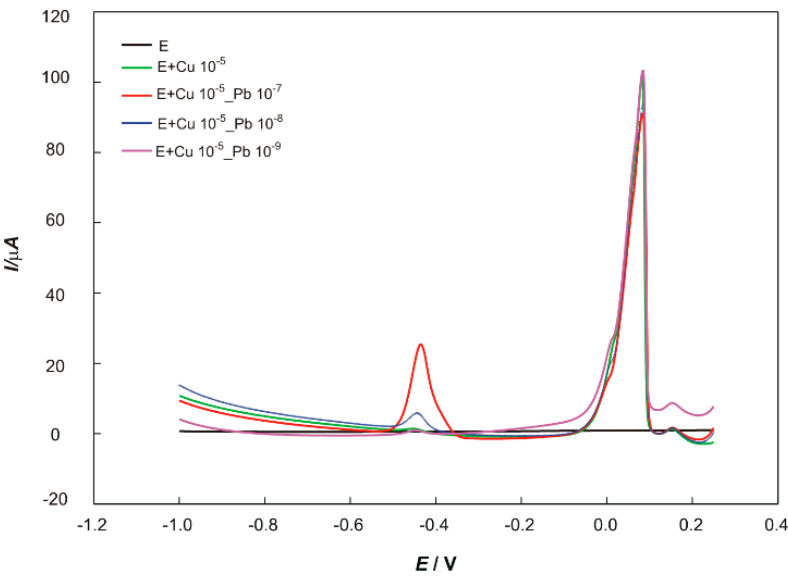

(a)

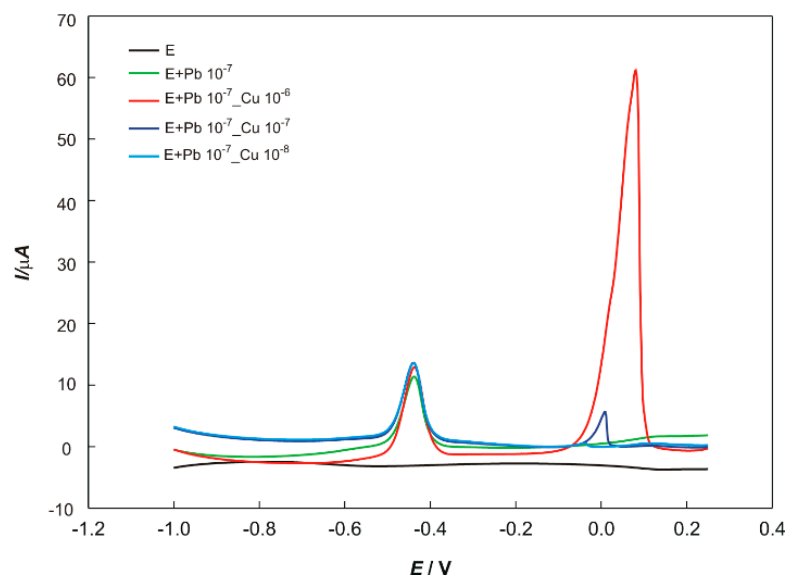

(b)

Figure 1. Square wave anodic stripping voltammogram of simultaneous detection of (a) lead at a constant concentration of copper; (b) copper at a constant concentration of lead at optimized parameters: electrodeposition potential and final potential of -1.5 and $+0.25 \mathrm{~V}$ respectively, electrodeposition time of $60 \mathrm{~s}$; step potential $=2 \mathrm{mV}$, step amplitude $=25 \mathrm{mV}$ and frequency $=10 \mathrm{~Hz}$.

\subsection{Determination of $\mathrm{Cu}(\mathrm{II})$ and $\mathrm{Pb}(\mathrm{II})$ in Real Samples}

The resulting stripping voltammograms for the seed sample are shown in Figure 2. 


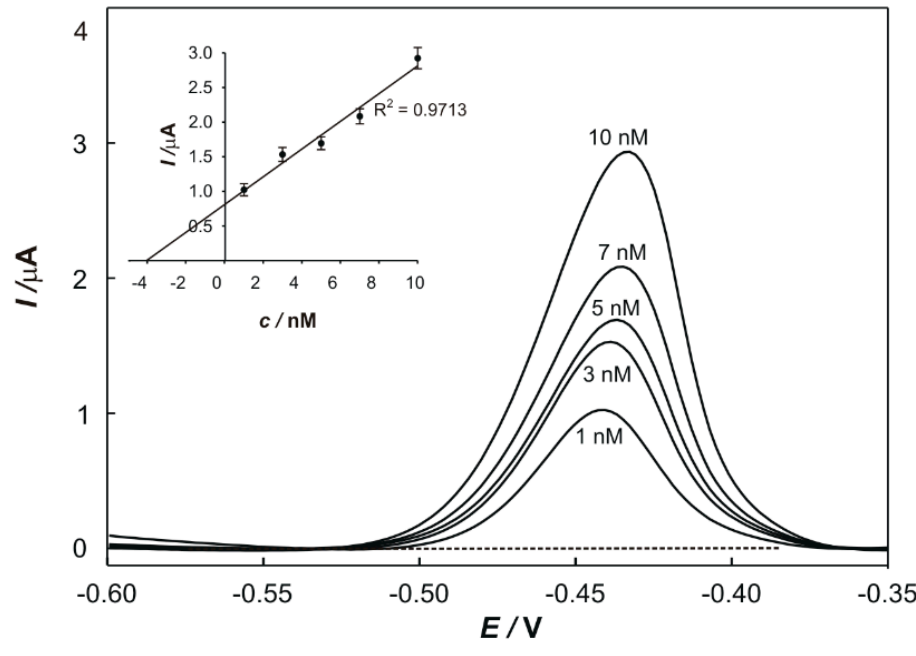

(a)

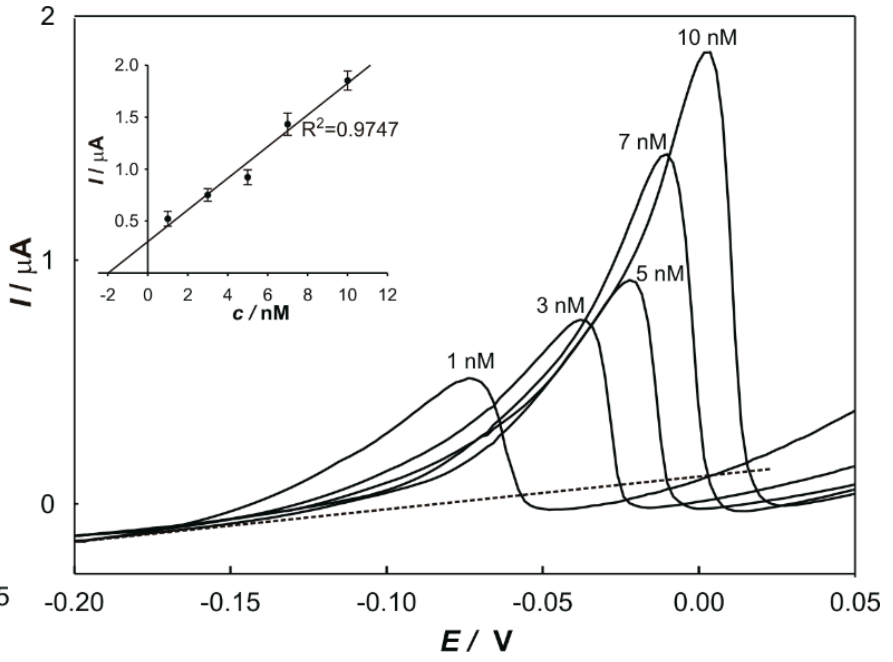

(b)

Figure 2. SWAS voltammogram recorded for seed sample with (a) increasing lead concentration and (b) increasing copper concentration. Inset: corresponding calibration curve. Optimized parameters: electrodeposition potential and final potential of -1.5 and $+0.25 \mathrm{~V}$, respectively, electrodeposition time of $60 \mathrm{~s}$; step potential $=2 \mathrm{mV}$, step amplitude $=25 \mathrm{mV}$ and frequency $=10 \mathrm{~Hz}$.

Redox signals for lead were observed at about $-0.45 \mathrm{~V}$. The peak potential for copper was $-0.07 \mathrm{~V}$, and it gradually shifted toward more negative potentials with an increase in heavy metal concentration.

Obtained voltammograms for the determination of metals in plant samples from S1 and S2, watered with tap water, are shown in Figures 3 and 4.

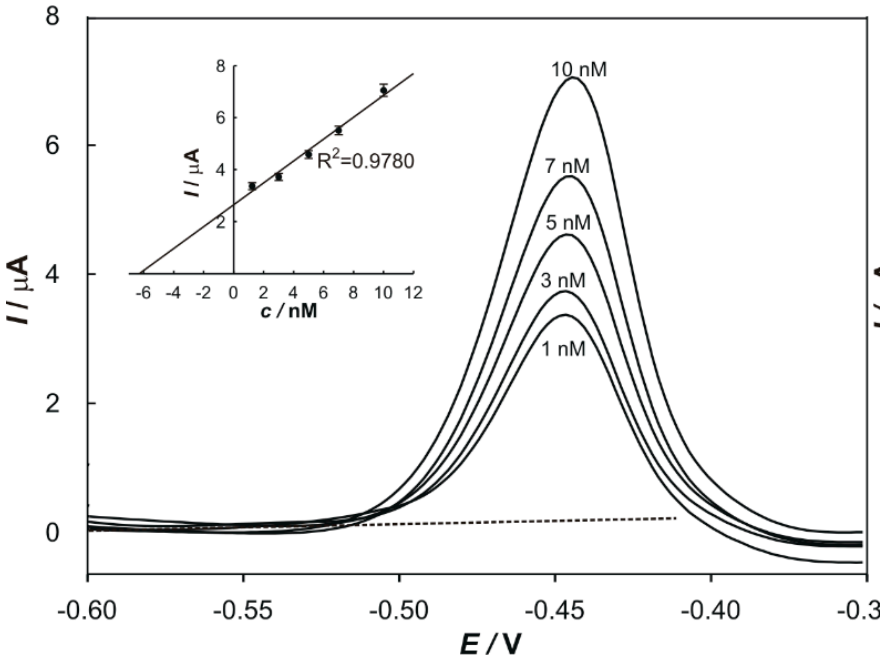

(a)

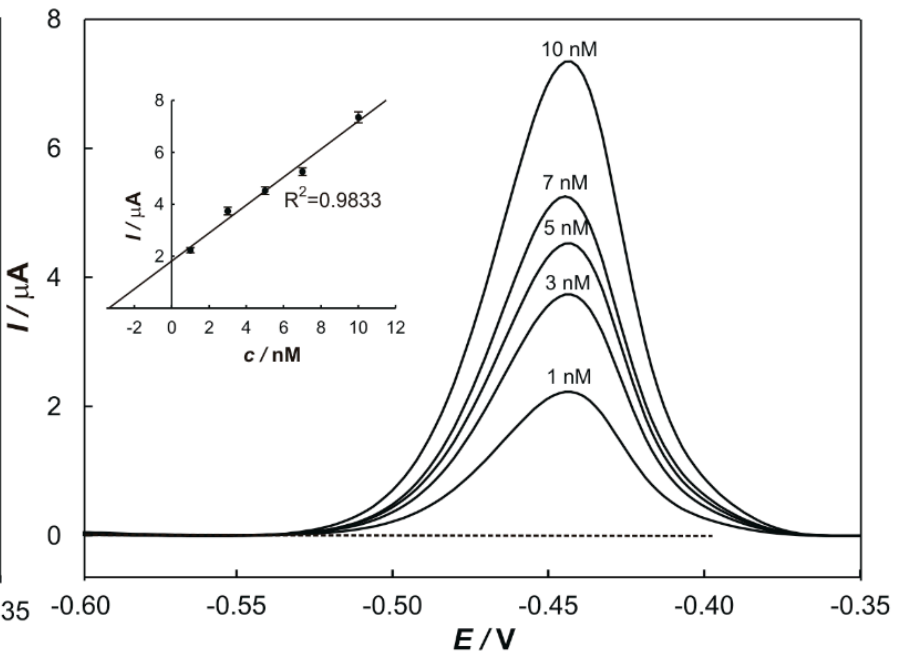

(b)

Figure 3. SWAS voltammogram of $\mathrm{Pb}$, with the corresponding calibration curve, recorded in plant samples from (a) S1; and (b) S2; watered with tap water, at optimized parameters: electrodeposition potential and final potential of -1.5 and $+0.25 \mathrm{~V}$, respectively, electrodeposition time of $60 \mathrm{~s}$; step potential $=2 \mathrm{mV}$, step amplitude $=25 \mathrm{mV}$ and frequency $=10 \mathrm{~Hz}$. 


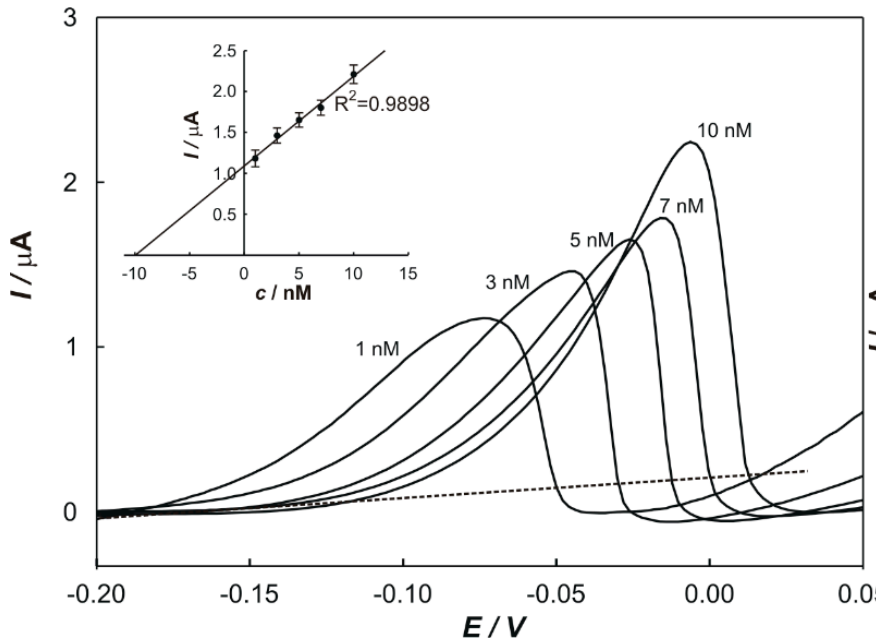

(a)

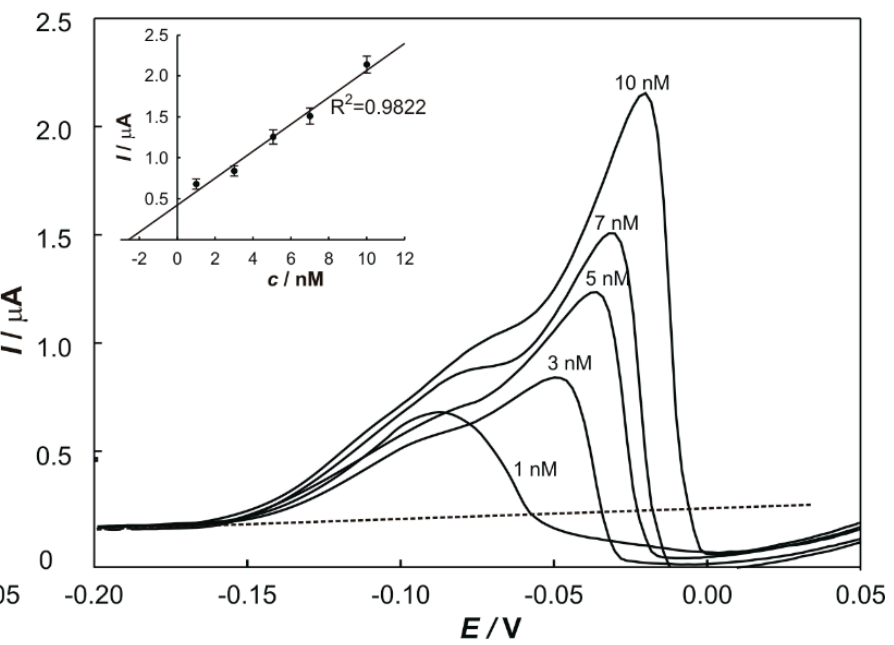

(b)

Figure 4. SWAS of $\mathrm{Cu}$, with the corresponding calibration curve, recorded in plant samples from (a) S1; and (b) S2; watered with water, at optimized parameters: electrodeposition potential and final potential of -1.5 and $+0.25 \mathrm{~V}$, respectively, electrodeposition time of $60 \mathrm{~s}$; step potential $=2 \mathrm{mV}$, step amplitude $=25 \mathrm{mV}$ and frequency $=10 \mathrm{~Hz}$.

The voltammograms obtained for the determination of metals in plant samples from $\mathrm{S} 1$ and S2, watered with prepared solution $(8 \mathrm{mM}$ for $\mathrm{Pb}$ and $8 \mathrm{mM}$ for $\mathrm{Cu})$, are shown in Figures 5 and 6, respectively.

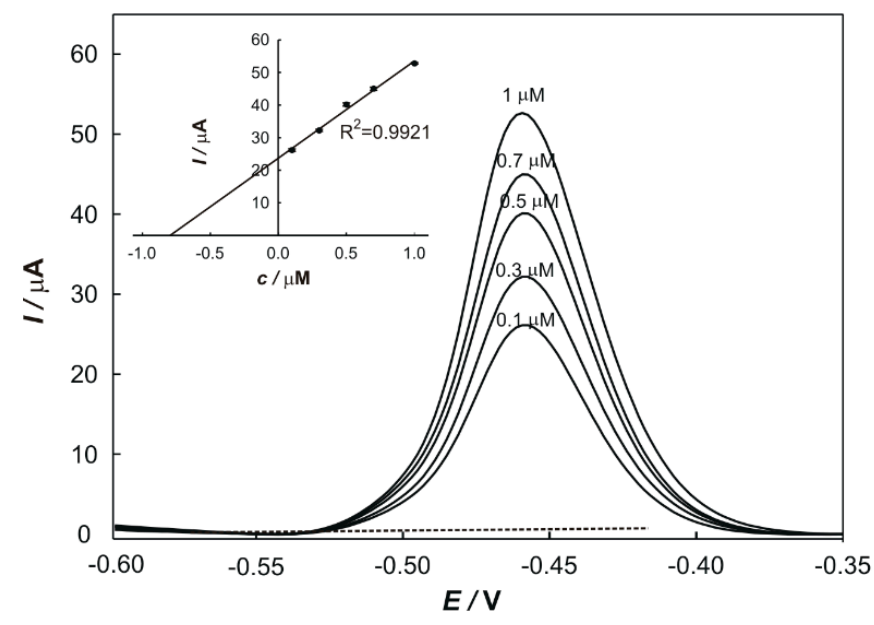

(a)

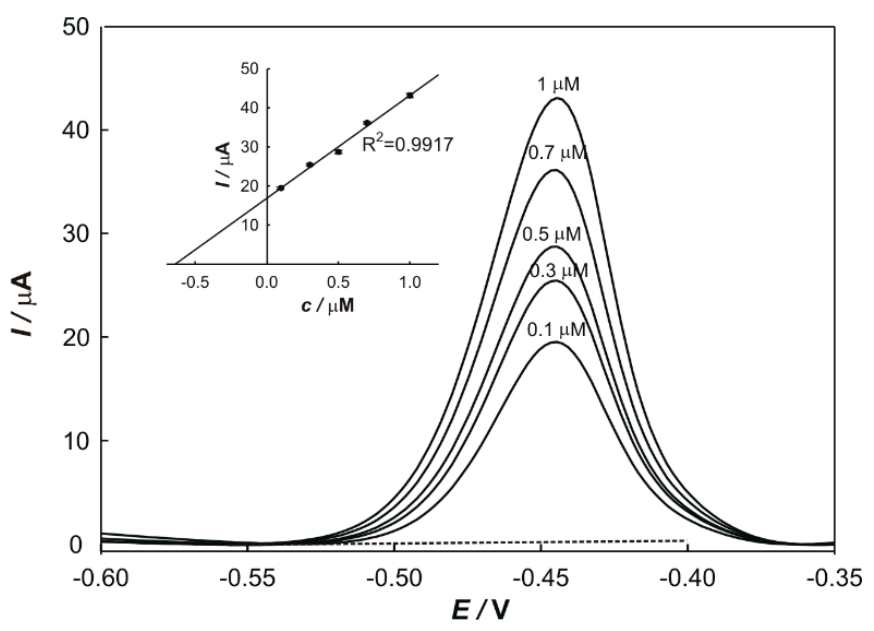

(b)

Figure 5. SWAS voltammogram of $\mathrm{Pb}$, with the corresponding calibration curve, recorded in plant samples from (a) S1; and (b) S2; watered with a prepared solution at optimized parameters: electrodeposition potential and final potential of -1.5 and $+0.25 \mathrm{~V}$, respectively, electrodeposition time of $60 \mathrm{~s}$; step potential $=2 \mathrm{mV}$, step amplitude $=25 \mathrm{mV}$ and frequency $=10 \mathrm{~Hz}$. 


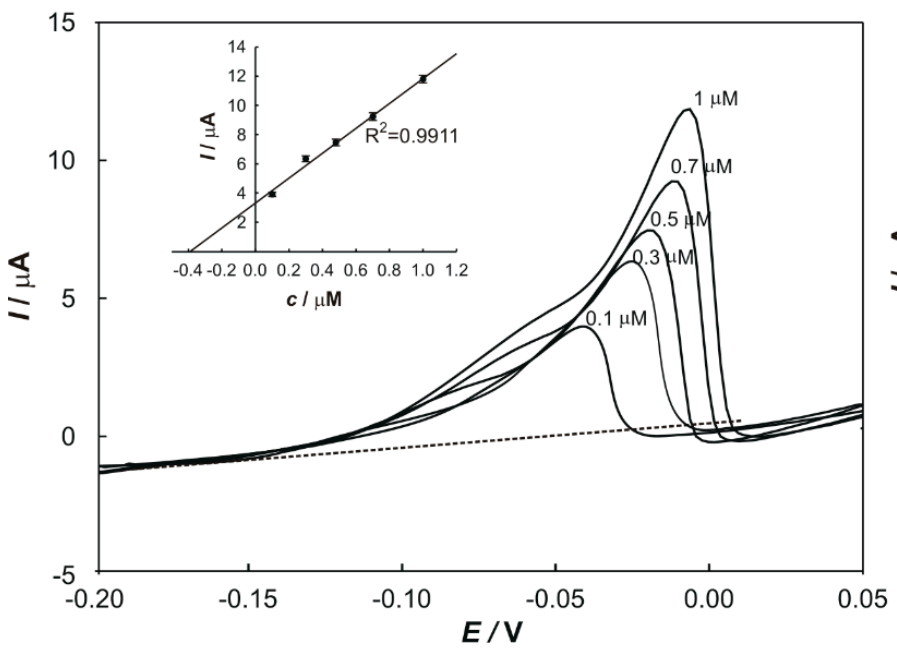

(a)

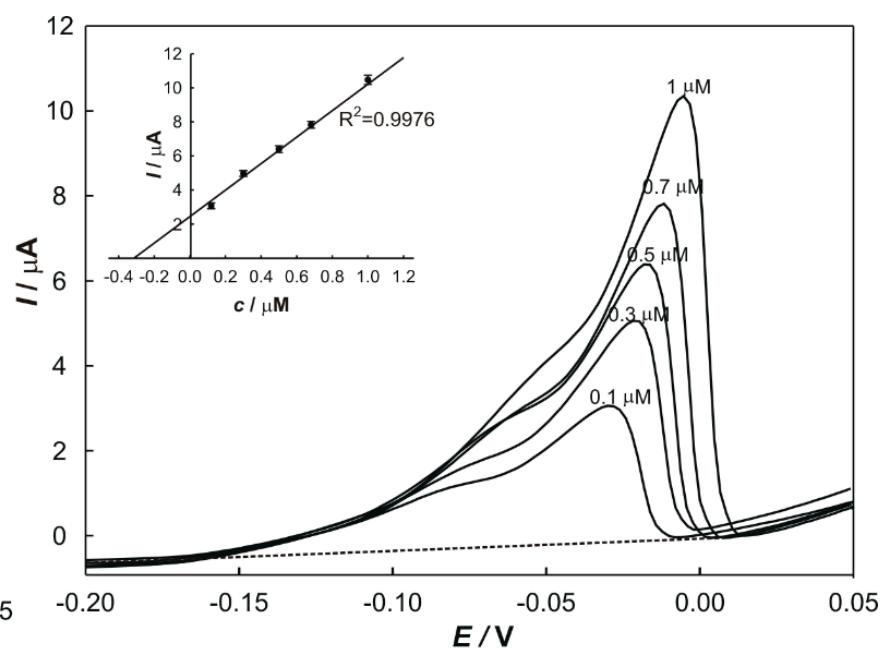

(b)

Figure 6. SWAS voltammogram of $\mathrm{Cu}$ with the corresponding calibration curve, recorded in plant samples from (a) S1; and (b) S2; watered with a prepared solution at optimized parameters: electrodeposition potential and final potential of -1.5 and $+0.25 \mathrm{~V}$, respectively, electrodeposition time of $60 \mathrm{~s}$; step potential $=2 \mathrm{mV}$, step amplitude $=25 \mathrm{mV}$ and frequency $=10 \mathrm{~Hz}$.

After 30 days of exposure, concentrations of $\mathrm{Cu}$ in the plant from S1 and S2 watered with tap water were $15.8 \pm 1.6$ and $4.1 \pm 0.6 \mathrm{mg} / \mathrm{kg}$, while the concentrations in the plants from S1 and S2 contaminated with a solution of $\mathrm{Pb} / \mathrm{Cu}$ were $624.2 \pm 23.4$ and $498.9 \pm 21.0 \mathrm{mg} / \mathrm{kg}$. Unlike for $\mathrm{Cu}$, concentrations of $\mathrm{Pb}$ in the plant from S1 and S2 watered with tap water or solution of $\mathrm{Pb} / \mathrm{Cu}$ were much higher in comparison with unseeded and untreated soil $(32.7 \pm 2.4$ and $17.5 \pm 1.6 \mathrm{mg} / \mathrm{kg} ; 4116.2 \pm 190.3$ and $3314.7 \pm 99.4 \mathrm{mg} / \mathrm{kg}$ ) (Table 1). The detection results were verified by inductively coupled plasma mass spectrometry (ICP-MS). A comparison of voltammetric and ICP-MS results are shown in Table 1.

Table 1. The comparison of voltammetric and ICP-MS results for the determination of $\mathrm{Pb}(\mathrm{II})$ and $\mathrm{Cu}(\mathrm{II})$ in the determined samples.

\begin{tabular}{|c|c|c|c|c|}
\hline \multirow[b]{2}{*}{ Sample $(n=5)$} & \multicolumn{2}{|c|}{ ICP } & \multicolumn{2}{|c|}{ SWASV } \\
\hline & Content of $\mathrm{Pb}(\mathrm{mg} / \mathrm{kg})$ & Content of $\mathrm{Cu}(\mathrm{mg} / \mathrm{kg})$ & Content of $\mathrm{Pb}(\mathrm{mg} / \mathrm{kg})$ & Content of $\mathrm{Cu}(\mathrm{mg} / \mathrm{kg})$ \\
\hline S1 & $25.7 \pm 0.8$ & $29.6 \pm 0.8$ & $23.8 \pm 1.8$ & $30.9 \pm 1.7$ \\
\hline S2 & $10.8 \pm 0.4$ & $10.8 \pm 0.5$ & $10.6 \pm 0.8$ & $11.3 \pm 0.9$ \\
\hline Seeds Lunaria & $1.6 \pm 0.1$ & $2.8 \pm 0.1$ & $2.1 \pm 0.3$ & $3.1 \pm 0.4$ \\
\hline $\mathrm{S} 1+\mathrm{H}_{2} \mathrm{O}$ & $25.5 \pm 0.8$ & $29.8 \pm 0.6$ & $26.9 \pm 1.5$ & $29.4 \pm 1.7$ \\
\hline $\mathrm{S} 1+\mathrm{Pb} / \mathrm{Cu}$ & $2194.4 \pm 22.4$ & $681.2 \pm 15.8$ & $2131.8 \pm 83.1$ & $701.7 \pm 36.1$ \\
\hline $\mathrm{S} 2+\mathrm{H}_{2} \mathrm{O}$ & $10.8 \pm 0.4$ & $10.6 \pm 0.5$ & $11.1 \pm 1.1$ & $10.6 \pm 0.8$ \\
\hline $\mathrm{S} 2+\mathrm{Pb} / \mathrm{Cu}$ & $2270.8 \pm 39.2$ & $715.8 \pm 13.3$ & $2232.5 \pm 75.9$ & $708.5 \pm 28.0$ \\
\hline Plant from $\mathrm{S} 1+\mathrm{H}_{2} \mathrm{O}$ & $28.8 \pm 0.8$ & $14.7 \pm 0.4$ & $32.7 \pm 2.4$ & $15.8 \pm 1.6$ \\
\hline Plant from $\mathrm{S} 1+\mathrm{Pb} / \mathrm{Cu}$ & $3845.5 \pm 52.1$ & $598.2 \pm 11.3$ & $4116.2 \pm 190.3$ & $624.2 \pm 23.4$ \\
\hline Plant from $\mathrm{S} 2+\mathrm{H}_{2} \mathrm{O}$ & $16.7 \pm 0.3$ & $4.0 \pm 0.1$ & $17.5 \pm 1.6$ & $4.1 \pm 0.6$ \\
\hline Plant from $\mathrm{S} 2+\mathrm{Pb} / \mathrm{Cu}$ & $3198.6 \pm 47.5$ & $501.0 \pm 12.5$ & $3314.7 \pm 99.4$ & $498.9 \pm 21.0$ \\
\hline
\end{tabular}

$n-$ number of samples in each determination. S1—soil from the Botanical Garden of the Faculty of Science, University of Split. S2—commercially available organic mineral substrate. 
In the table, it can be clearly observed that the results obtained from the proposed method are almost the same as those provided using the ICP-MS. This confirms the practical utility of the proposed method for metal ion detection in real samples.

According to the data listed on the product label, S2 contains $12.3 \mathrm{mg} / \mathrm{kg}$ of copper and $10.22 \mathrm{mg} / \mathrm{kg}$ of lead, which corresponds to the values obtained in these experiments. Higher values of $\mathrm{Cu}$ concentrations in $\mathrm{S1}$ could be explained by the fact that it is an agricultural area where vine grapes were planted from where the sample was obtained. Namely, years ago, in the northern part of the botanical garden, autochthonous Mediterranean plant cultures were cultivated (vineyards, olive groves, etc.). In addition, vines were grown near the botanical garden on the slopes of the Marjan forest. It is known that the vines were sprayed with a mixture of copper sulphate, lime and water, popularly known as Bordeaux mixture. In addition, most of the plants in the botanical garden were also repeatedly sprayed with the Bordeaux mixture.

The permissible level of $\mathrm{Pb}$ and $\mathrm{Cu}$ in agricultural areas in Croatia is $0-50 \mathrm{mg} / \mathrm{kg}$ and $0-60 \mathrm{mg} / \mathrm{kg}$ [16]. Data in Table 1 show that $\mathrm{Pb}$ and $\mathrm{Cu}$ levels in the soil samples were under the permissible limit. The values obtained in this work corresponded to those found for the concentrations of $\mathrm{Pb}$ and $\mathrm{Cu}$ in soil and plants from Brassicaceae families [17].

Concentrations of metals in the samples of plants presented in Table 1 showed that concentrations of $\mathrm{Pb}$ in the plant from soils which were watered with tap water are slightly higher than in unseeded and untreated soil, while $\mathrm{Cu}$ concentrations did not change significantly.

The amount of lead and copper in plant samples that were watered with a solution of $\mathrm{Pb} / \mathrm{Cu}$ significantly increased as related to the soil contamination level (S1 and S2). Similar behavior was observed in the article of Herrero et al. [2].

Although the added concentrations of lead and copper were high, the plant did not wither, which suggests that the Lunaria annua L. have mechanisms to tolerate the presence of heavy metals in the substrate which they grow in. The results showed that Lunaria annua L., according to the criteria for hyperaccumulation [8], is a lead hyperaccumulator and a potential copper accumulator.

According to the literature [1,18], with increasing soil $\mathrm{pH}$, the availability of metals in the soil decreases, so it is more difficult for plants to accept them, i.e., the higher the soil $\mathrm{pH}$, the lower the possibility of metal accumulation. The measured $\mathrm{pH}$ values show that soil $1(\mathrm{pH}=6.35)$ is poorly acidic to neutral. On the other hand, the purchased organic soil $2(\mathrm{pH}=8.58)$ is moderately alkaline soil. So, the obtained results show that the higher the $\mathrm{pH}$, the lower the possibility of metal accumulation. Considering the measured $\mathrm{pH}$ values of the investigated soils, this could explain the significantly lower concentrations obtained for copper compared to lead.

\section{Conclusions}

The experiments showed that SWASV could be used successfully to determine metals, particularly copper and lead, in contaminated soils and plant samples. Moreover, such a technique may be a good alternative to spectroscopy due to its simplicity and lower equipment costs.

Obtained concentrations for copper in plants from both types of soil watered with tap water are lower in comparison to the unseeded and untreated soil. Unlike copper, lead concertation in plants from both types of soil watered with tap water were much higher in comparison with unseeded and untreated soil. This confirms the well-known fact that for the bioavailability of copper, the optimal $\mathrm{pH}$ should be between 4.5 and 6 , while the mobility of lead does not depend on $\mathrm{pH}$ value.

The obtained results showed that the higher the $\mathrm{pH}$, the lower the possibility of metal accumulation.

Various species of the Brassicaceae family are known to hyperaccumulate metals. Our results suggest that Lunaria annua L. is capable of accumulating toxic amounts of copper and lead. None of the plant samples accumulated copper in concentrations above $1000 \mathrm{mg} \mathrm{kg}^{-1}$, meaning the criteria for a hyperaccumulator were not met. However, given 
the obtained concentration values, we can conclude that Lunaria annua L. is a potential copper accumulator and a heavy metal-tolerant species. In contrast to the obtained values of copper, the values for lead were greater than $1000 \mathrm{mg} \mathrm{kg}^{-1}$, indicating that Lunaria annua $\mathrm{L}$. is a hyperaccumulator of lead. Hence, the results presented in this paper indicate a possible health risk if the plant material of Lunaria annua L. were used for human consumption.

Author Contributions: Conceptualization, M.B. (Maša Buljac); methodology, M.B. (Maša Buljac), M.B. (Marijo Buzuk) and J.R.; validation, M.B. (Marijo Buzuk), J.R., D.K. and M.B. (Maša Buljac); formal analysis, N.V. and I.Š.R.; investigation, M.B. (Maša Buljac), M.B. (Marijo Buzuk) and A.M.; resources, M.B. (Maša Buljac) and J.R.; writing—original draft preparation, M.B. (Maša Buljac); writing-review and editing, M.B. (Maša Buljac), M.B. (Marijo Buzuk), J.R. and D.K.; visualization, M.B. (Maša Buljac); supervision, M.B. (Marijo Buzuk) All authors have read and agreed to the published version of the manuscript.

Funding: The authors acknowledged the financial support received from the Croatian Science Foundation under the projects BioSMe (Grant IP-2016-06-1316).

Institutional Review Board Statement: Not applicable.

Informed Consent Statement: Informed consent was obtained from all subjects involved in the study.

Data Availability Statement: Not applicable.

Conflicts of Interest: The authors declare no conflict of interest.

\section{References}

1. Nagajyoti, P.C.; Lee, K.D.; Sreekanth, T.V.M. Heavy metals, occurrence and toxicity for plants: A review. Environ. Chem. Lett. 2010, 8, 199-216. [CrossRef]

2. Herrero, E.M.; López-Gonzálvez, A.; Ruiz, M.A.; Lucas-García, J.A.; Barbas, C. Uptake and Distribution of Zinc, Cadmium, Lead and Copper in Brassica napus var. oleífera and Helianthus annus Grown in Contaminated Soils. Int. J. Phytoremediat. 2003, 5, 153-167. [CrossRef] [PubMed]

3. Kiliç, H.D.; Deveci, S.; Dönmez, K.B.; Çetinkaya, E.; Karadağ, S.; Doğu, M. Application of stripping voltammetry method for the analysis of available copper, zinc and manganese contents in soil samples. Int. J. Environ. Anal. Chem. 2018, 98, 308-322. [CrossRef]

4. Marschner, H. Mineral Nutrition of Higher Plants; Academic Press: London, UK, 2012; p. 672.

5. Prasad, M.N.V.; Freitas, H.M. Metal hyperaccumulation in plants-Biodiversity prospecting for phytoremediation technology. Electron. J. Biotechnol. 2003, 6, 285-321. [CrossRef]

6. Peng, J.S.; Guan, Y.H.; Lin, X.J.; Xu, X.J.; Xiao, L.; Wang, H.H.; Meng, S. Comparative understanding of metal hyperaccumulation in plants: A mini-review. Environ. Geochem. Health 2021, 43, 1599-1607. [CrossRef] [PubMed]

7. Auguy, F.; Fahr, M.; Moulin, P.; Brugel, A.; Laplaze, L.; El Mzibri, M.; Filali-Maltouf, A.; Doumas, P.; Smouni, A. Lead Tolerance and Accumulation in Hirschfeldia incana, a Mediterranean Brassicaceae from Metalliferous Mine Spoils. PLoS ONE 2013, 8, 1-10. [CrossRef] [PubMed]

8. Baker, A.J.M.; Brooks, R.R. Terrestrial Higher Plants which Hyperaccumulate Metallic Elements-A Review of their Distribution. Ecol. Phytochem. Biorecovery 1989, 1, 81-126.

9. Sarma, H. Metal Hyperaccumulation in Plants; A Rewiev focusing on Phytoremediation Technology. J. Environ. Sci. Technol. 2011, 4, 118-138. [CrossRef]

10. Krämer, U. Metal Hyperaccumulation in Plants. Annu. Rev. Plant Biol. 2010, 61, 517-534. [CrossRef] [PubMed]

11. Abdullahi, U.A.; Khandaker, M.M.; Mat Shaari, N.E.; Abdelmoaty, S.; Badaluddin, N.A.; Alias, N. Implications of Brassicaceae cultivation in heavy metals contaminated environment: A phytoremediation point of view. Biosci. Res. 2021, 18, 906-913.

12. Mastebroek, H.D.; Marvin, H.J.P. Breeding prospects of Lunaria annua L. Ind. Crops Prod. 2000, 11, 139-143. [CrossRef]

13. Walker, R.L.; Walker, K.C.; Booth, E.J. Adaptation potential of the novel oilseed crop, Honesty (Lunaria annua L.), to the Scottish climate. Ind. Crops Prod. 2003, 18, 7-15. [CrossRef]

14. Al-Hossainy, A.F. Simultaneous determination of $\mathrm{Cd}(\mathrm{II})$ and $\mathrm{Cu}(\mathrm{II})$ using stripping voltammetry in groundwater, soil and Alhagi maurorum plants in industrial and urban areas in Northern Border, Saudi Arabia with luminol as a chelating agent. Water Sci. Technol. 2015, 72, 1127-1139. [CrossRef] [PubMed]

15. Banda, M.F.; Mokgalaka, N.S.; Combrinck, S.; Regnier, T. Five-weeks pot trial evaluation of phytoremediation potential of Helichrysum splendidum Less. for copper- and lead-contaminated soils. Int. J. Environ. Sci. Technol. 2021, 18, 1-12. [CrossRef]

16. Ordinance on the Protection of Agricultural Land from Pollution; Ministry of Agriculture, Official Gazette: Zagreb, Croatia, 2014; Volume 9. 
17. Yoon, J.; Cao, X.; Zhou, Q.; Ma, L.Q. Accumulation of $\mathrm{Pb}, \mathrm{Cu}$, and $\mathrm{Zn}$ in native plants growing on a contaminated Florida site. Sci. Total Environ. 2006, 368, 456-464. [CrossRef] [PubMed]

18. Tomović, G.M.; Mihailović, N.L.; Tumi, A.F.; Gajić, B.A.; Mišljenović, T.D.; Niketić, M.S. Trace metals in soils and several brassicaceae plant species from serpentine sites of Serbia. Arch. Environ. Prot. 2013, 39, 29-49. [CrossRef] 